\title{
Small Cell Carcinoma
}

National Cancer Institute

\section{Source}

National Cancer Institute. Small Cell Carcinoma. NCI Thesaurus. Code C3915.

A neuroendocrine carcinoma composed of small malignant cells which are often said to resemble "oat cells" under the microscope. Small cell carcinoma most often affects the lungs. Clinically, this is often a rapidly growing cancer that spreads to distant sites early. 